\title{
DIGITALISASI GEREJA KRISTEN JAWA SALATIGA TIMUR: SOLUSI PELAYANAN JEMAAT DI TENGAH PANDEMI COVID-19
}

\author{
Suharyadi'1), Evi Maria ${ }^{1)}$, Adriyanto Juliastomo Gundo'), Irwan Sembiring') \\ ${ }^{1)}$ Fakultas Teknologi Informasi, Universitas Kristen Satya Wacana, Salatiga, Jawa Tengah, Indonesia \\ Corresponding author : Evi Maria \\ E-mail : evi.maria@uksw.edu
}

Diterima 07 Februari 2021, Direvisi 22 Februari 2021, Disetujui 23 Februari 2021

\begin{abstract}
ABSTRAK
Covid-19 membawa dampak pembatasan kegiatan keagamaan tatap muka di gereja untuk mencegah terbentuknya klaster penyebaran Covid-19 di gereja. Tujuan kegiatan pengabdian kepada masyarakat ini adalah melakukan digitalisasi di GKJ Salatiga Timur dengan cara membangun website untuk GKJ Salatiga Timur. Metode pelaksanaan kegiatan ini, ada dua. Pertama, pembangunan website gereja. Kedua, pelatihan dan pendampingan administrator yang bertugas untuk mengelola dan memelihara website gereja. Peserta kegiatan ini ada 12 orang. Hasil kegiatan ini, adalah tersedianya website GKJ Salatiga Timur yang dapat diakses di http://gkjsalatigatimur.org. Website gereja menjadi media publikasi dan komunikasi antara pengurus gereja dan jemaatnya. Informasi tentang kegiatan gereja bisa diakses jemaat melalui website. Tak hanya itu, rekaman ibadah online setiap minggunya, baik untuk ibadah umum maupun ibadah sekolah minggu juga sudah dapat diakses oleh jemaat melalui website gereja. Hasil pelatihan administrator website, anggota Komisi Multimedia dan Petugas Administrasi GKJ Salatiga Timur sudah dapat melakukan pemeliharaan dan pembaharuan informasi terkait kegiatan pelayanan jemaat di GKJ Salatiga Timur.
\end{abstract}

Kata kunci: digitalisasi; gereja; pelayanan jemaat; Covid-19.

\begin{abstract}
Covid-19 brings the impact of restrictions on face-to-face religious activities in churches to prevent the formation of clusters of Covid-19 spread in churches. The purpose of community service activity is to digitize GKJ Salatiga Timur by building a website for GKJ Salatiga Timur. Methods of implementing this activity, first, building a church website. Second, training and mentoring administrators the church website. There are 12 participants in this activity. This activity was carried out by the construction of church websites and training administrators in charge of managing and maintaining church websites. The result of this activity is the availability of GKJ Salatiga Timur website that can be accessed in http://gkjsalatigatimur.org. Website church becomes a medium of publication and communication between church administrators and their congregations. Information about church activities can be accessed by the congregation through the website. Not only that, recordings of online worship every week, both for public worship and sunday school worship can also be accessed by the congregation through the church's website. The result of administrator training, members of the Multimedia Commission and the Administration Officer of GKJ Salatiga Timur have been able to maintain and update information related to church service activities in GKJ Salatiga Timur.
\end{abstract}

Keywords: digitization; church; church ministry; Covid-19.

\section{PENDAHULUAN}

Pemerintah Indonesia menetapkan Covid-19 sebagai bencana nasional di Indonesia, sejak dikeluarkannya Keputusan Presiden No. 12/2020, tanggal 13 April 2020 yang lalu. Namun sampai sekarang, pandemi Covid-19 masih belum menunjukkan tanda akan berakhir. Pandemi mengubah kehidupan sosial masyarakat di Indonesia. Masyarakat dituntut untuk beradaptasi dengan virus sampai ditemukan vaksin dan imunisasi masal dilakukan (Maria, 2020).
Kebijakan pembatasan sosial berskala terbatas dan besar, seperti yang diatur dalam UU No. 6/2018 tentang Kekarantinaan Kesehatan dan Peraturan Pemeritah No. 21/2020 diambil pemerintah dalam upaya meminimalisasi penyebaran virus corona di masyarakat. Pembatasan dilakukan salah satunya dengan membatasi kegiatan keagamaan. Gereja sebagai persekutuan tentunya sangat merasakan dampak dari pemberlakuan kebijakan pemerintah ini. Hasil survei Komisi Litbang Persekutuan Gereja- 
Gereja Indonesia (PGI) menemukan bahwa 79,3 persen responden setuju untuk mengikuti himbauan pemerintah untuk tidak berkumpul dengan anggota jemaat dan tidak melakukan aktivitas keagamaannya di gereja. Dari total 79,3 persen tersebut, ada sebanyak 95,4 persen responden, setuju untuk melakukan kegiatan ibadah online, saat pandemi Covid-19 berlangsung, sedangkan sisanya, yaitu 4,6 persen responden menyatakan tidak setuju (Saragih, 2020).

Dwiraharjo (2020) menemukan bahwa pada masa pandemi Covid-19 ini, banyak gereja-gereja di Indonesia, sedang menghadapi permasalahan terkait dengan pelaksanaan ibadah, dan masing-masing gereja memiliki pendapatnya sendiri bagaimana menyikapi kondisi di masa pandemi ini. Tidak sedikit gereja bersikap pura-pura tidak tahu, masa bodoh, bahkan menentang terkait pembatasan aktivitas keagamaan di gereja dan tetap melakukan ibadah dengan pola lama dengan berkumpul di gereja. Tak heran, kondisi ini membuat gereja menjadi klaster baru penyebaran Covid-19, seperti 3 gereja di DKI Jakarta dengan total 29 kasus (Rahayu, 2020) dan 1 gereja di Palangkaraya dengan total 49 kasus (Andika, 2020), bahkan klaster Covid-19 pada gereja di Pati telah menelan korban jiwa, yaitu 2 pendeta meninggal karena terjangkit virus ini (Herlambang, 2020). Kondisi ini tentunya tidak dapat dibiarkan begitu saja. Gereja perlu solusi pelayanan pada jemaat yang baru ditengah pandemi ini, yaitu dengan mengimplementasikan digitalisasi gereja.

Digitalisasi gereja, diharapkan mampu untuk mengurangi aktivitas berkerumun para anggota jemaat di gereja, namun tujuan utama untuk menyampaikan firman kepada jemaat dapat terlaksana. Gereja Kristen Jawa (GKJ) Salatiga Timur, adalah salah satu gereja yang mendukung penerapan kebijakan pemerintah untuk membatasi aktivitas ibadah di gereja. Selama pandemi ini, GKJ Salatiga Timur tidak mengadakan ibadah dengan pola lama. Ibadah minggu dan ibadah lainnya, dilakukan menggunakan rekaman ibadah. Petugas ibadah tiap minggunya akan melaksanakan rekaman untuk ditanyakan pada jam-jam ibadah gereja. Saat ini, rekaman tersebut diupload di channel youtube gereja. Namun prosedur yang cukup panjang harus dilalui para anggota jemat untuk bisa sampai ke channel youtube gereja, banyak kali dikeluhkan oleh anggota jemaat lanjut usia (lansia). Jemaat lansia sedih karena tidak bisa beribadah selama Covid-19 karena kesulitan memilih channel dan konten ibadah di youtube. Permasalahan lainnya, GKJ Salatiga Timur juga tidak bisa memberikan informasi terkini terkait pelayanan dan kondisi gereja, akuntabilitas keuangan gereja, serta kondisi jemaat dengan cepat karena tidak memiliki media publikasi berita-berita tersebut selama masa pandemi ini. Oleh sebab itu, digitalisasi GKJ Salatiga Timur perlu dilakukan sebagai solusi pelayanan jemaat di tengah pandemi Covid-19.

Tujuan program pengabdian kepada masyarakat ini adalah melakukan digitalisasi di GKJ Salatiga Timur dengan cara membangun website untuk GKJ Salatiga Timur. Website gereja adalah media yang efektif untuk penyampaian informasi kepada jemaat gereja saat pandemi (Dien et al., 2020). Website dapat menampilkan seluruh informasi yang berhubungan dengan pelayanan di gereja, tidak hanya dalam bentuk teks dan gambar, tetapi juga dalam bentuk video. Fitur menu-menu dalam website, membuat informasi sudah ditata dan ditampilkan sesuai dengan kebutuhan gereja, sehingga memudahkan jemaat untuk mencari dan mengakses informasi sesuai kebutuhannya.

\section{METODE}

Kegiatan pengabdian kepada masyarakat ini dilakukan di Gereja Kristen Jawa (GKJ) Salatiga Timur selama empat bulan, mulai dari bulan Oktober 2020 sampai bulan Januari 2021. Mitra kegiatan pengabdian ini adalah Majelis Jemaat GKJ Salatiga Timur, Komisi Multimedia, dan Pegawai Administrasi Gereja (Tata Usaha), dengan total peserta sebanyak 12 orang. Metode pelaksanaan program Digitalisasi GKJ Salatiga Timur, yaitu dengan membangun website gereja, serta pelatihan dan pendampingan administrator website bagi anggota Komisi Multimedia dan Pegawai Administrasi GKJ Salatiga Timur.

Digitalisasi GKJ Salatiga Timur dilakukan dengan cara membangun website gereja. Tahapan pembangunan website gereja disajikan pada Gambar 1. Pertama, tahap pengumpulan data yang dilakukan dengan cara diskusi dan wawancara dengan para pemangku kepentingan, yaitu Pendeta, Ketua Majelis Jemaat, dan Ketua Komisi Multimedia GKJ Salatiga Timur. Hasil diskusi, dikelompokkan berdasarkan jenis dan kepentingan untuk dimasukkan ke dalam menu-menu yang akan ditampilkan dalam website nantinya.

Kedua, tahap perancangan dan evaluasi prototipe. Perancangan prototipe website menggunakan informasi yang diperoleh dari tahap sebelumnya. Rancangan website masih bersifat sementara untuk dikonsultasikan dengan calon pengguna, yaitu GKJ Salatiga Timur. Tahap ini berguna untuk evaluasi serta melakukan koreksi atas rancangan dan 
informasi yang akan disajikan. Rancangan sementara yang dibuat difokuskan kepada pengguna. Pada tahap ini Tim Pengabdi terus melakukan komunikasi dan pengembangan rancangan website sesuai dengan kebutuhan pengguna. Penjelasan cara kerja sistem juga disampaikan pada tahap ini.

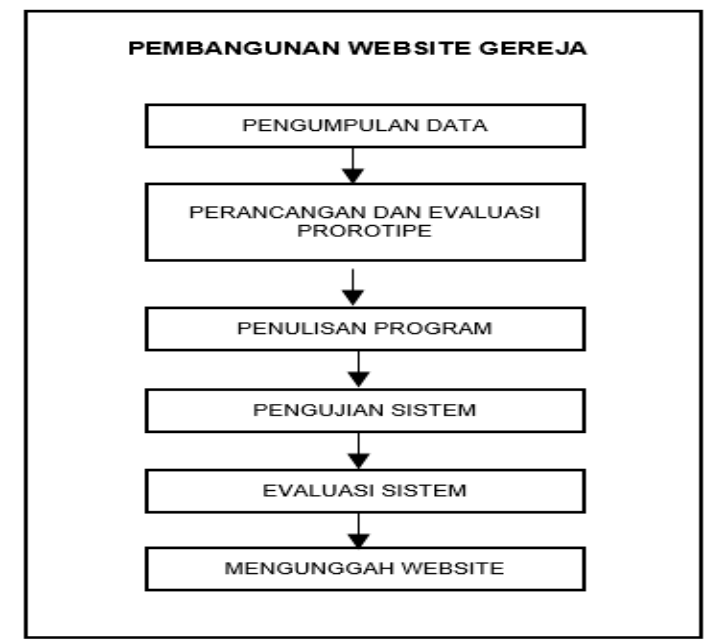

Gambar 1 Tahapan Pembangunan Website

Ketiga, tahap pembuatan website. Pada tahap ini, pembuatan website dilakukan dengan mengacu pada prototipe yang sudah disetujui bersama antara Tim Pengabdi sebagai pengembang website dengan calon pengguna, yaitu GKJ Salatiga Timur. Dalam pelaksanaan pembangunannya, Tim Pengabdi masih tetap melibatkan calon pengguna, sehingga proses tanya jawab dan diskusi masih tetap dilakukan dalam tahap ini. Tujuannya, agar website yang dibangun benar-benar memenuhi kebutuhan pengguna. Pembangunan website juga perlu mempertimbangkan efisiensi dan kemudahan dalam pemeliharaan serta meminimalkan ketergantungan kepada Tim Pengabdi setelah program sudah berakhir. Oleh sebab itu, website dibangun menggunakan Content Management System (CMS), yaitu wordpress karena website yang dibangun dengan platform tersebut dapat memenuhi spesifikasi kebutuhan pengguna dan mengurangi ketergantungan dengan pengembang sistem informasi (Siambaton \& Fakhriza, 2016; Zulkarnain et al., 2020).

Keempat, tahap pengujian sistem. Tujuannya, agar Tim Pengabdi dapat mengetahui terlebih dahulu dan langsung memperbaiki jalannya program jika masih terdapat kekeliruan, sehingga risiko kegagalan implementasi perangkat lunak dapat diminimalisir (Komarudin, 2016). Pengujian sistem dilakukan sebelum aplikasi website diunggah ke internet.
Kelima, tahap evaluasi sistem. Pada tahap ini, website secara keseluruhan dievaluasi, apakah sudah berjalan sesuai yang diharapkan. Tujuannya, agar website lebih sempurna dan diketahui secara dini sebelum diunggah ke internet. Evaluasi dilakukan oleh calon pengguna, yaitu dari komisi multimedia beserta Majelis Jemaat GKJ Salatiga Timur.

Keenam, tahap mengunggah website. Tahap akhir dari proses pembangunan website GKJ Salatiga Timur adalah pengunggahan website ke domain melalui jasa layanan hosting. Tahap ini dilakukan setelah mendapatkan persetujuan dari calon pengguna. Setelah website diunggah ke internet, maka website GKJ Salatiga Timur sudah bisa diakses oleh siapapun dan dari manapun. Website yang terunggah sudah bisa diisi konten oleh administrator website, yaitu anggota Komisi Multimedia dan Petugas Administrasi GKJ Salatiga Timur. Administrator akan dilatih dan didampingi cara untuk mengelola website oleh Tim Pengabdi.

Keberhasilan kegiatan pengabdian kepada masyarakat ini diukur menggunakan dua indikator. Pertama, tersedianya website GKJ Salatiga Timur yang dapat diakses dan menampilkan kegiatan pelayanan. Kedua, ada administrator website GKJ Salatiga Timur yang dapat melakukan pengelolaan website, yang ditunjukkan dengan jumlah upload konten di website GKJ Salatiga Timur

\section{HASIL DAN PEMBAHASAN}

Kegiatan pengabdian kepada masyarakat, digitalisasi GKJ Salatiga Timur ini dilaksanakan dari bulan Oktober 2020- Januari 2021. Kegiatan pembangunan website gereja dimulai dari tanggal 2 Oktober 2020 sampai dengan tanggal 23 Desember 2020. Sedangkan, kegiatan pelatihan dan pendampingan administrator dan operator website gereja dilakukan mulai tanggal 28 Desember 2020 sampai dengan tanggal 31 Januari 2021. Peserta kegiatan ini berjumlah 12 orang.

\section{Website Gereja sebagai Solusi Pelayanan Jemaat di Tengah Pandemi Covid-19}

Sebelum sesi diskusi dan wawancara dilakukan untuk pengumpulan data, Tim Pengabdi terlebih dahulu menjelaskan website gereja sebagai solusi pelayanan jemaat di tengah pendemi Covid-19. Kegiatan ini dilaksanakan tanggal 2 Oktober 2020. Peserta kegiatan ini adalah Pendeta, Ketua Majelis Jemaat, dan Ketua Komisi Multimedia GKJ Salatiga Timur.

Teknologi internet, menjadi salah satu solusi model pelayanan dan penyampaian 
informasi kepada orang lain tanpa harus bersentuhan fisik. Website merupakan salah satu pilihan untuk diterapkan dalam rangka meningkatkan pelayanan kepada anggota jemaat. Ada lima alasan penerapan teknologi website sebagai solusi pelayanan gereja pada anggota jemaat di tengah pandemi Covid- 19 .

Pertama, website gereja menjadi solusi untuk mengumpulkan informasi kegiatan pelayanan di gereja dan tempat untuk menyiarkan rekaman ibadah online yang dilakukan selama pandemi Covid-19. Fitur menu khusus untuk ibadah memudahkan anggota jemaat untuk mengakses acara ibadah online setiap minggunya.

Kedua, website menjadi solusi efektif bagi pengurus gereja untuk tetap memberikan informasi dan berkomunikasi dengan anggota jemaatnya. Sebagian besar gereja memberikan buletin gereja atau warta jemaat kepada anggotanya setelah ibadah selesai setiap minggunya. Namun, banyak dari anggota jemaat mungkin lupa untuk mengambil buletin tersebut, atau jika tidak lupa, seringkali jemaat kehilangan setelah seminggu. Dengan memiliki website gereja sendiri, buletin gereja dapat dipublikasikan pada media tersebut, sehingga anggota jemaat dapat memperoleh informasi yang dibutuhkan kapan dan dari mana saja. Informasi terkait pelayanan, kegiatan, bahkan sampai informasi pelaporan keuangan dapat dipublikasikan di website gereja. Dengan demikian, gereja dapat beroperasi lebih efisien karena dapat mengurangi biaya mencetak buletin gereja, namun tujuan komunikasi, transparansi dan akuntabilitas gereja tetap tercapai.

Ketiga, melalui website, gereja dapat menjangkau orang-orang yang mungkin tidak pernah ke gereja. Ini adalah cara yang efektif untuk mendapatkan anggota jemaat baru dan membantu orang-orang yang mungkin berada di luar jangkuan secara fisik. Banyak orang yang takut datang ke gereja secara pribadi dan akan mengunjungi website gereja untuk mengikuti ibadah secara online. Melalui konten di website, gereja memberi kesempatan luar biasa untuk memberi tahu masyarakat tentang apa itu gereja dan apa yang masyarakat dapat peroleh jika mengikuti pelayanan di gereja baik secara online maupun tatap muka (offline).

Keempat, gereja dapat menggunakan website resmi gereja untuk mengumpulkan donasi secara online. Jemaat tidak ragu untuk memberi karena website adalah website gereja dan dikelola resmi oleh pelayan Tuhan di gereja tersebut. Ini membuka kesempatan bagi gereja untuk melakukan lebih banyak hal untuk kegiatan pelayanan pada anggota dan komisi.
Kelima, website gereja dapat mengurangi secara signifikan jumlah panggilan telepon dan pertanyaan mengenai waktu layanan dan informasi dasar tentang jam layanan gereja. Gereja dapat mempublikasikan waktu layanan gereja di website gereja dan juga dapat menyertakan petunjuk arah mengemudi menuju ke gereja, yang dapat membantu orang-orang yang sedang bepergian untuk menemukan dan mengunjungi gereja.

Setelah menjelaskan manfaat website gereja saat pandemi Covid-19, sesi dilanjutkan dengan diskusi untuk memetakan dan mengelompokkan informasi yang akan dipublikasikan di website gereja. Suasana diskusi di GKJ Salatiga Timur disajikan pada Gambar 2. Dari hasil diskusi, informasi dikelompokkan ke dalam menu-menu dalam website. Adapun menu website GKJ Salatiga Timur, antara lain menu kemajelisan, visi misi, dan sejarah gereja, Pepanthan, komisi-komisi, alamat dan kontak, berita dan artikel, serta galeri dan kalender gerejawi.

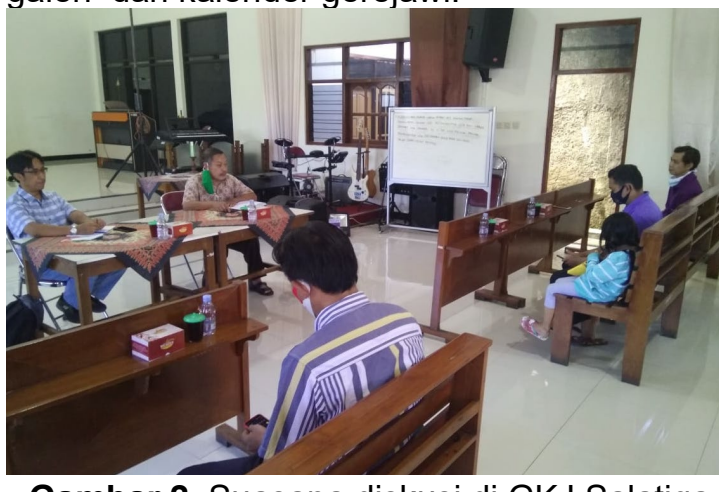

Gambar 2. Suasana diskusi di GKJ Salatiga Timur

\section{Pembangunan Webiste GKJ Salatiga Timur}

Website GKJ Salatiga Timur telah di

hosting. Adapun alamat domain dari website gereja adalah http://gkjsalatigatimur.org. Halaman muka website GKJ Salatiga Timur disajikan pada Gambar 3 dan menu yang ada pada website gereja disajikan pada Gambar 4 . GKJ Salatiga Timur memiliki empat bidang, yaitu bidang ibadah, bidang kesaksian dan pelayanan, bidang pembinaan warga gereja dan bidang penata layanan. Ada 14 komisi dibawah empat bidang tersebut. Ini membuat konten website GKJ Salatiga Timur sangat beragam dan cukup banyak informasi yang harus dipublikasikan dan diperbarui disana. Oleh sebab itu, diperlukan orang yang bertanggung jawab terhadap pemeliharaan dan pembaharuan konten website tersebut. 


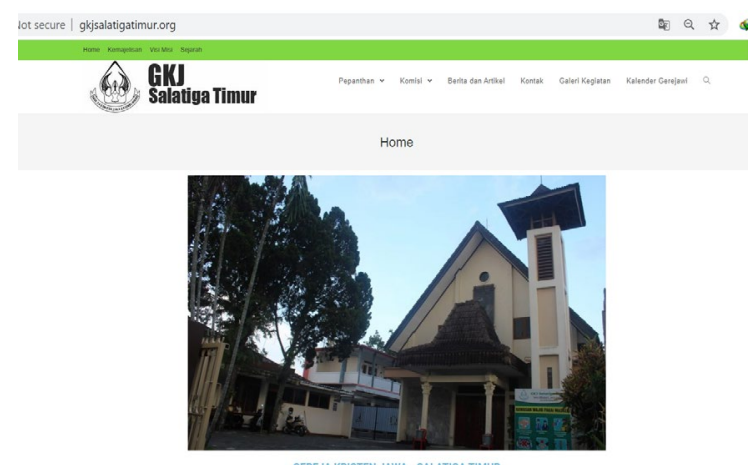

Gambar 3. Website GKJ Salatiga Timur

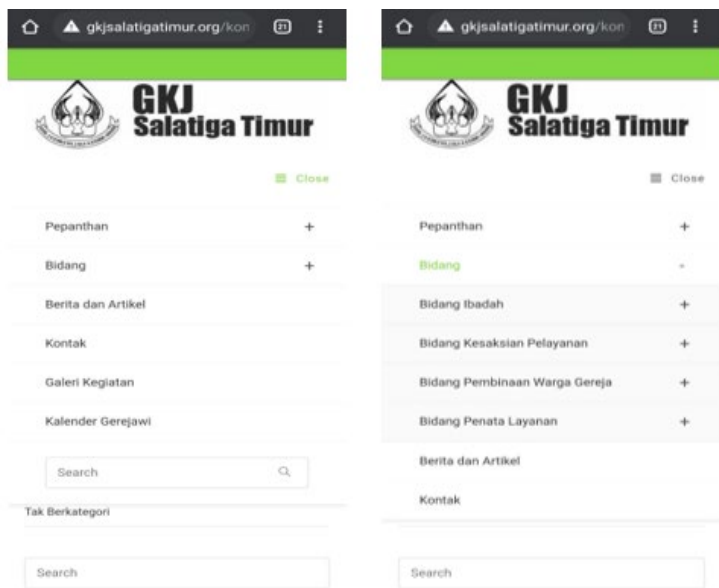

Gambar 4. Menu Website GKJ Salatiga Timur

Proses update informasi tidak akan berjalan dengan maksimal jika hanya dilakukan oleh satu orang saja, untuk itu Tim Pengabdi membagi beberapa user untuk diberi tanggungjawab dalam mengelola website. Pengelolaan user (user management) website ditunjukkan pada tabel 1 . Jumlah pengelola website berjumlah 8 orang dengan rincian 1 orang sebagai administrator, 2 orang sebagai editor, dan 5 orang sebagai kontributor.

Tabel 1. User Management Website Gereja

\begin{tabular}{lccc}
\hline \multicolumn{1}{c}{ Hak Akses } & Administrator & Editor & Kontributor \\
\hline Mengelola halaman pos & $\sqrt{ }$ & $\sqrt{ }$ & $\begin{array}{c}\text { menambahkan, menyunting, } \\
\text { menghapus post sendiri }\end{array}$ \\
\hline Mengelolan halaman web & $\sqrt{ }$ & $\sqrt{ }$ & - \\
\hline Mengunggah berkas & $\sqrt{ }$ & $\sqrt{ }$ & - \\
\hline Mengatur komentar & $\sqrt{ }$ & $\sqrt{ }$ & - \\
\hline Instalasi program tambahan Plugin & $\sqrt{ }$ & - & - \\
\hline Mengatur Tema & $\sqrt{ }$ & $\cdot$ & - \\
\hline Mengelola Pengguna & $\sqrt{ }$ & - & menyunting milik sendiri \\
\hline Melakukan Pengaturan & $\sqrt{ }$ & - & - \\
\hline
\end{tabular}

Setelah website GKJ Salatiga Timur berhasil dibangun maka diadakan pelatihan untuk para pengelola website gereja. Kegiatan pelatihan untuk administrator dilakukan pada tanggal 28 Desember 2020, sedangkan pelatihan untuk editor dilakukan pada tanggal 29 Januari 2021. Gambar 5 menunjukkan suasana saat pelatihan editor website gereja dilakukan. Para editor website diajari bagaimana cara untuk membuat konten, memasukan gambar dan video dan mengunggahnya pada website gereja.

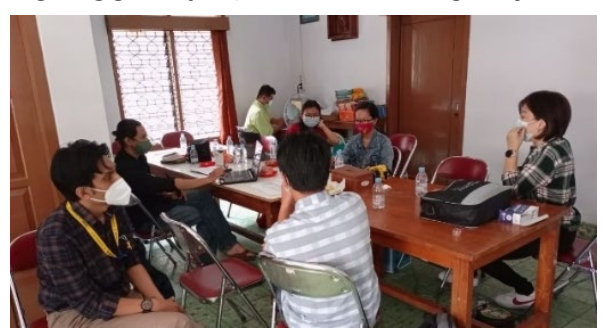

Gambar 5. Suasana Pelatihan Editor Website

\section{Capaian Kegiatan Pengabdian Kepada Masyarakat \\ Website GKJ Salatiga Timur sudah} mulai beroperasi sejak 3 Desember 2020. Data per 6 Februari 2021 menunjukkan bahwa GKJ Salatiga Timur sudah menggunakan website gereja untuk mempublikasikan pengumuman terkait kegiatan ibadah dan kegiatan pelayanan gereja lainnya. Pengelola website mengunggah informasi tersebut dalam menu berita dan artikel, sedangkan foto-foto kegiatan yang sudah terlaksana di gereja diunggah pada menu galeri kegiatan, seperti yang disajikan pada Gambar 6.

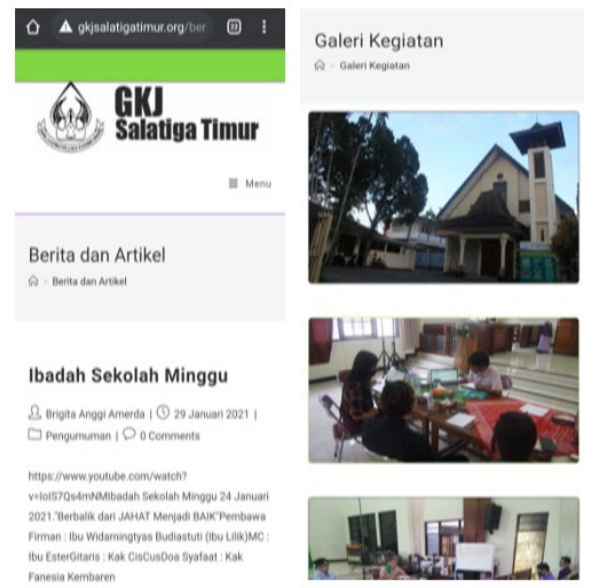

Gambar 6. Unggahan Berita dan Galeri Kegiatan di Website GKJ Salatiga Timur

Tak hanya untuk kepentingan publikasi acara dan kegiatan, website gereja pun sudah digunakan untuk mengunggah rekaman ibadah online setiap minggunya. Rekaman ibadah yang diunggah di website gereja tidak hanya rekaman ibadah umum saja, tetapi juga rekaman ibadah online untuk anak-anak. Ini menunjukkan bahwa penggunaan website tidak hanya membantu memudahkan anggota jemaat yang dewasa dan usia lanjut, tetapi juga anak-anak. Unggahan rekaman ibadah online dan ibadah sekolah minggu GKJ Salatiga Timur disajikan pada Gambar 7 dan Gambar 8. 


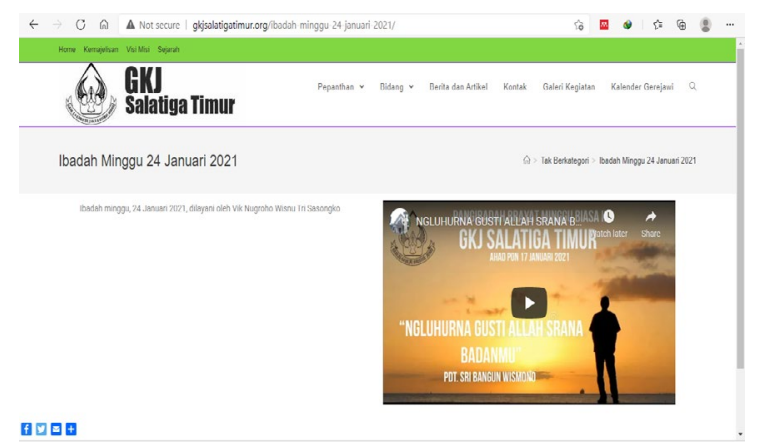

Gambar 7. Unggahan Rekaman Ibadah Online

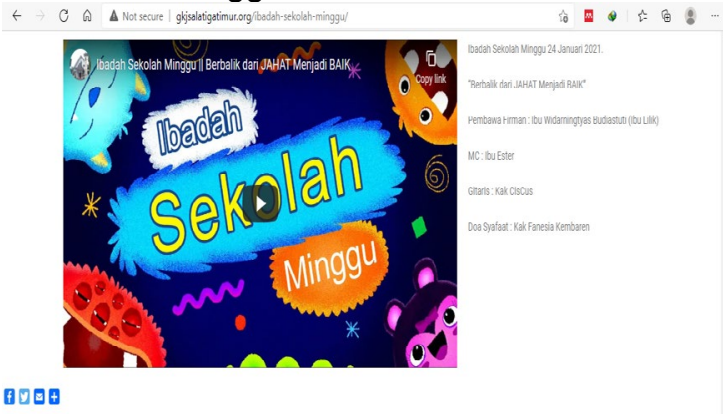

Gambar 8. Unggahan Rekaman Ibadah Sekolah Minggu Online

\section{SIMPULAN DAN SARAN}

Hasil kegiatan pengabdian kepada masyarakat ini adalah digitalisasi kegiatan pelayanan jemaat menggunakan website gereja khusus untuk GKJ Salatiga Timur. Website gereja dapat diakses di http://gkjsalatigatimur.org. Website ini digunakan sebagai media untuk memberikan informasi dan komunikasi antara pengurus gereja, pelayan gereja dan jemaat gereja. Website menjadi solusi pelayanan jemaat ditengah pandemi Covid-19, saat pemerintah Indonesia menerapkan kebijakan pembatasan aktivitas keagamaan yang menimbulkan kerumunan di gereja agar gereja tidak menjadi klaster penyebaran Covid-19. Ibadah online sudah dapat diakses melalui website gereja. Pengelola website sudah berhasil menggunakan website untuk kegiatan pelayanan jemaat yang ditunjukkan oleh unggahan berita terbaru terkait pelayanan jemaat di website tersebut.

Namun, masih ada beberapa hambatan terkait pengelolaan website di GKJ Salatiga Timur. Pertama, anggota Komisi Multimedia masih mengalami kesulitan untuk menulis konten dan berita di website karena belum memiliki pengetahuan dan pengalaman terkait menulis berita. Oleh sebab itu, kegiatan pelatihan untuk penulisan berita perlu dilakukan untuk editor website GKJ Salatiga Timur. Kedua, banyak dokumen-dokumen sejarah dan administrasi gereja yang perlu untuk dibuat dalam bentuk digital, namun jika dikerjakan hanya oleh pengurus gereja, maka memerlukan waktu yang lama untuk bisa mengtransformasi ke bentuk digital. Oleh sebab itu, GKJ Salatiga Timur membutuhkan relawan dari anggota jemaat untuk mempercepat proses transformasi tersebut.

\section{DAFTAR RUJUKAN}

Andika, R. (2020, December). Warga Positif Covid-19 dari Cluster Gereja di Palangkaraya Bertambah. AntaraNews. Com.

Dien, M. E., Esna, J., \& Radjabaycolle, T. (2020). Analisis Kualitas Website Dan Channel Youtube Gereja Katolik Paroki St Maria Bintang Laut Ambon Sebagai Media Komunikasi Dan Pelayanan Di Masa Pandemi. Jurnal Ekonomi, Sosial \& Humaniora, 02(02), 46-54.

Dwiraharjo, S. (2020). Konstruksi Teologis Gereja Digital: Sebuah Refleksi Biblis Ibadah Online di Masa Pandemi Covid19. EPIGRAPHE: Jurnal Teologi Dan Pelayanan Kristiani, 4(1), 1. https://doi.org/10.33991/epigraphe.v4i1 .145

Herlambang, A. A. (2020, September). Gereja di Pati Jadi Klaster Covid-19, 2 Pendeta Meninggal. AyoSemarang.Com. https://www.ayosemarang.com/read/20 20/09/26/64336/gereja-di-pati-jadiklaster-covid-19-2-pendeta-meninggal

Keputusan Presiden Nomor 12 (2020) Penetapan Bencana Non Alam Penyebaran Corona Virus Disease 2019 (COVID-19) Sebagai Bencana Nasional. Indonesia

Komarudin, M. (2016). Pengujian perangkat Lunak metode Black box berbasis partitions pada aplikasi sistem informasi di sekolah. Jurnal Mikrotik, o6(3), 02-16.

Maria, E. (2020). Digitalisasi Ekonomi Desa Memasuki Era Kenormalan Baru. In T. C. Leasiwal (Ed.), Perkembangan Perekonomian Indonesia saat Serangan Pandemi Covid-19 (Vol. 1, pp. 25-58). CV. AA. Rizky.

Peraturan Pemerintah No. 21 (2020) Pembatasan Sosial Berskala Besar Dalam Rangka Percepatan Penanganan Corona Virus Disease 2019 (COVID-19). https://jdih.setkab.go.id/PUUdoc/17608 5/PP_Nomor_21_Tahun_2020.pdf

Rahayu, L. S. (2020, July). Gereja di DKI jadi Jadi Klaster Corona, PGI Lebih Baik Ibadah dari RUmah. DetikNews.Com.

Saragih, M. (2020). Potret Wajah Gereja di Masa Pandemi Covid-19 (Berita PGI). https://pgi.or.id/potret-wajah-gereja-di- 
masa-pandemi-covid-19/

Siambaton, M. Z., \& Fakhriza, M. (2016). Aplikasi Content Management System (Cms) Pada Joomla Untuk Membuat Web Service. InfoTekJar (Jurnal Nasional Informatika Dan Teknologi Jaringan), 1(1), 11-13. https://doi.org/10.30743/infotekjar.v1i1. 32

Undang-Undang Nomor $6 \quad$ (2018) Kekarantinaan Kesehatan. Indonesia.

Zulkarnain, A., Tirtana, A., \& Susanto, D. W. S. (2020). Sistem Informasi Karya Inovatif berbasis CMS Wordpress Studi Kasus STIKI Malang. Jurnal IImiah Teknologi Informasi Asia, 14(2), 93. https://doi.org/10.32815/jitika.v14i2.47 4 